\title{
Internal Management Integration Policies and School-Community Relations in Tertiary Institutions in Rivers State
}

\author{
Sam-Kalagbor, Osaruchi Victoria, Osuji, Catherine U. \\ Department of Educational Management, Faculty of Education, Rivers State University, Rivers State, Nigeria \\ Corresponding Author: Sam-Kalagbor
}

\begin{abstract}
The study investigated internal management integration policies and school-community relations in Tertiary Institutions in Rivers State. Two research questions and two hypotheses guided the study. The study adopted correlational design. The population of the study is 1,071 respondents. A sample of 535 respondents was drawn using simple random sampling technique. Two sets of instruments were used for data collection. The first was titled: 'Internal Management Integration Policies Questionnaire and the second was School-Community Relations Questionnaire. The reliability of 0.83 was determined with Cronbach Statistics. Out of 535 copies of questionnaire administered, 508 were properly filled and retrieved which represented 95\% return rate. The Research questions were answered using Pearson Product Moment Correlation (PPMC) while Hypotheses were tested using r-ratio at 0.05 level of significance. The finding among others are that high positive relationship exists between award of contracts to community members and school-community relations and the null hypothesis of no significant relationship between award of contracts to community members and schoolcommunity relations is rejected. It was concluded that internal management integration policies have high positive relationship to school-community relations in Tertiary Institutions in Rivers State. It was recommended among others that higher institutions' administration should give full implementation to local content laws during the award of contracts in the school environment.
\end{abstract}

Keywords: Internal, management, Integration, Policies, School-Community.

\section{INTRODUCTION}

Today many leaders in education, business and the community have come to realize that schools alone cannot prepare our youths for productive adulthood. In recent time, there are institutional internal management integration policies that schools and communities should work closely with each other to meet their mutual goals. The school administrators work to promote school-community relations through the participation of the school in community activities, programmes and projects, and community participation in the activities of the school. This can be achieved by means of organized visits to places of interests in the community. It is important for school administrators to maintain regular contacts with some external institutions such as government agencies, non-governmental and civil society organizations and the public educational development partners and industries (Okoroma, 2017).

Partnerships should be considered as connections between schools and community resources. The partnership may involve use of school or neighborhood facilities and equipment; sharing other resources; collaborative fund raising and grant applications; volunteer assistance; monitoring and training from professionals and others with special expertise, 
information sharing and dissemination; networking, recognition, public relations and internal management integration policies.

Internal management integrates the interests of communities and their members in her polices in both the award and execution of contracts. Award of contracts to community members demands creating an enabling environment where considerations for award of contracts are preferentially given to qualified and competent contractors from or nominated by the community. This gesture is capable of creating cordial school-community relations. However, planning comes to play in this regard. With the help of effective planning, heads of tertiary institutions can objectively achieve meaningful results in the school-community relations.

Scholarship scheme is part of internal management integration policies and that can be used by heads of tertiary institutions to engender good schoolcommunity relations. Scholarship scheme is the privilege and preference granted to some indigent and well deserving persons who have performed creditably well in the field of their academic endeavors. These privileges are usually extended to community members as a way of integrating them into the school system.

\section{Purpose of the Study}

The study examined the relationship between internal management integration policies and school-community relations in Rivers State. The objectives sought to:

1. access the extent of relationship between award of contracts to members of the community and school-community relations in Tertiary Institutions in Rivers State.

2. investigate the extent of relationship between award of scholarships to students from the community and school-community relations in Tertiary Institutions in Rivers State.

\section{Research Questions}

The following research questions guided this study:

1. What is the extent of relationship between award of contracts to community members and schoolcommunity relations in Tertiary Institutions in Rivers State?

2. What is the extent of relationship between award of scholarship to students from the community and school-community relations in Tertiary Institutions in Rivers State?

\section{Hypotheses}

The following hypotheses guided this study:

1. There is no significant relationship between award of contracts to community members and schoolcommunity relations in Tertiary Institutions in Rivers State.

2. There is no significant relationship between award of scholarships to students from the community and school-community relations in Tertiary Institutions in Rivers State.

\section{Reviews \\ Systems Theory}

The System Theory is a multidisciplinary theory. It was proposed in the 1940s by a biologist named Ludwig Von Bertalanffy and further developed by Ross Ashby in 1956 among others in 1958 cited in (Famade, 2015). It views an organization as a social system of symbolically interested interdependent parts. This means that an organization can be seen as a structure with interdependent parts, each having a supra system which constitutes its environment. The basic idea in a system is that the parts of any link are so related and interdependent that the interaction of any part affects the whole. The educational system as an organization is a social system with tertiary institutions as a sub-system of the educational system. For the system and its subsystem to survive, it must be open with its unit of interdependent parts, characteristics, activities that contribute to, and receive from the whole. 
That is, they must have the capacity to relate to and exchange matters with their environment, unlike a closed system which does not. For instance, when the head of a tertiary institution is confronted with parental demands on the need for introduction of a new course, not only is the administrator affected directly, the teaching staff, non-teaching staff and students are equally affected one way or the other.

\section{Internal Management Integration Policies}

According to Aderonmu and Ehiametalor (2012), internal management integration policy is "essentially a service, activity or tool through which the fundamental objectives of the educational process may be more fully and efficiently realized". In a related definition, the National Society for the Study of Education (NSSE) has defined internal management integration policies as "social statesmanship which guides educational activities, plans, programmes mid facilities and provides leadership in a long term but social broad perspective". The focus of internal management integration policy is to enhance and sustain quality teaching, learning, research and community relations. Generally, the functions and processes of internal management integration policies include but are not limited to resource and programme planning, policy making and implementation; financial mobilization and administration. Others are provision and management of infrastructure and instructional facilities/materials, personnel/ students services, advisory and discipline.

Internal management integration policies and educational management are used interchangeably by many scholars, even though some differentiate between internal management integration policies and educational management. Notwithstanding that the same principles guide them, the narrow differences between the two are that whereas educational management is very much concerned with achievement of results, goals and objectives, internal management integration policies emphasize compliance with the laws, established rules, procedures and regulations (due process) necessary for the realization of educational goals and objectives similarly. In educational management, results are easily measurable, in internal management integration policies, results are not easily measurable and while educational management is progressive, dynamic imaginative, creative and innovative, internal management integration policies is generally flexible in its approach and methodology.

\section{School-community Relations}

Since the school and the community are like, each is expected to play rules that are complimentary to the other. On the part of the school, it calls for regular and effective communication between the management of the school and the leadership and members of the community; formulation of community-friendly policies, support for, design and effective implementation of community-based development projects and programmes as well as holding periodic consultative meetings with the leadership and accredited representatives to the community on matters of mutual interests and benefits. Such matters will include admission of students, members of the community into the school, security, employment, contract and scholarship awards. Others are access to use of school facilities and internship opportunities, etc, on its part, aside from providing land for the location of the school and for agricultural extension programme, the community is expected to assist in the protection of lives and property of the school and its members, support the implementation of the policies and decisions of the school and generally participate and contribute to the realization of the objects and mandate of the school. Essentially, the success of the school is deemed to be the success of the community and conversely. 


\section{Contract Awards}

Generally, contract awards refer to situations in which a company or the government or an institution procures the services of a person or corporate entity to execute a project, programme or provide some specific services. Award of contracts to the community implies creating an enabling environment where considerations for project execution or provision of social are preferentially given to the host community its members or persons/nominated or recommended by it firms. This gesture is sufficient and substantial enough to enhance schoolcommunity relations (Ihebereme, 2018).

Institutions may recognize contractors from the community in the execution of contracts within the school, but where consideration for the award of contracts is increased for the host community, this is likely to better the school community relations. In the process of contract awards, prospective contactors are usually requested to submit bids to the hiring organization or institution. It is imperative to note that contract award is a strategic method in which the heads of tertiary institutions can use in promoting school-community relations. Occasionally, the institutions carry out some projects as it affects the school, the heads of tertiary institutions during such periods can engage the community members with some level of contracts. This is to empower the community members, instill ownership and protective spirit in the community and ultimately enhance school-community relations.

\section{Scholarship Awards}

A scholarship is an award of financial aid for a student to further their education at a private elementary or secondary school, or a private or public post-secondary college, university, or other academic institutions. Scholarships are awarded based upon various criteria, such as need, merit, diversity and inclusion and, athletic skills, among others, or some combination of criteria. Scholarship criteria usually reflect the values and goals of the donor or founder of the award. While scholarship recipients are not required to repay scholarships, the awards may require that the recipient continue to meet certain requirements during their period of support, such as maintaining a minimum grade point average or engaging in a certain activity.

Scholarship award, especially to indigent and exceptionally gifted members of the community is also useful to heads of tertiary institutions when trying to promote harmonious school-community relations. Heads of tertiary institution can strategically adopt this gesture to enhance their relationship with the community. School as an open system and a social organization thrives on the effective interrelationship within it and with its relevant communities. What happens in a school affects the community, and what happens in the community affects school (Nwankwo, Nwokafor, Ogunsanwo \& Ighalo, 2015). This means that community builds its schools and the schools build their communities (Sidhu, 2017).

The processes of social interaction are the bases for creating social relationship. According to Calhoun, Light and Keller (2013) social relationships are relatively enduring patterns of interaction between two or more people. Most people have many social relationships, from casual acquaintance to intimate friendships and close family bond. School community relationship is a two-way symbiotic arrangement through which the school and the community co-operate with each other for the realization of goals of the community and vice versa.

The school is a special environment where a certain quality of life types of activities and occupations are provided with the object of securing child's development along desirable lines (Mishra, 2017). The function of the traditional school was to transmit the social heritage of the community. Its role was too academic in nature. The modern sociological view of 
education lay down that the school constantly draws upon social life and activities for its subject matter, its methods of teaching and its methods of work. There must be a conscious and continuous intercourse, a free give and take between the little world of the school and bigger one outside.

\section{METHODOLOGY}

The study adopted correlational design. The population of the study is 1,071 respondents and consisted of 681 Principal Officers, Senate/Academic Board members in the eight tertiary institutions in Rivers State. It also consisted of 390 community leaders from the host communities comprising members of the Community Development Committees, youths, women groups and opinion leaders. A sample of 535 respondents was drawn for the study using simple random sampling technique. Two sets of instruments were used for data collection. The first was titled: 'Internal Management Integration Policies Questionnaire (IMIPQ) and the second was School-Community Relations Questionnaire (SRQ).

The questionnaire were structured on a five point Rating Scale, weighted as Very
High Extent (VHE -5-points), High Extent (HE-4-points), Moderate Extent (ME - 3,points), Low Extent (LE -2-points) and Very Low Extent (VLE -1-point). Two sets of instrument were given to two experts in Test and Measurement for validity. The reliability of the instrument was determined with Cronbach Alpha Statistics with an index of Internal Management Integration Policies Questionnaire 0.83 and Schoolcommunity relations 0.87 . Out of 535 copies of questionnaire administered, 508 were properly filled and retrieved which represented 95\% return rate and analyzed. The Research questions were answered using Pearson Product Moment Correlation (PPMC) formula. Hypotheses were tested using r-ratio at 0.05 level of significance with 506 degrees of freedom using Statistical Packages in Social Sciences (SPSS) version 23.00.

\section{RESULTS}

Research Question 1: What is the extent of relationship between award of contracts to community members and schoolcommunity relations in Tertiary Institutions in Rivers State?

Table 1: Pearson Product Moment Correlation Analysis on the Relationship between award of contracts to community members and School-community relations

\begin{tabular}{|c|c|c|c|c|c|c|c|}
\hline Variable & $\sum$ & $\sum^{2}$ & $\mathbf{N}$ & $\mathbf{D f}$ & $\sum \mathbf{X Y}$ & $\mathbf{r}$ & Decision \\
\hline Award of contracts to community members (X) & 10197 & 2123 & & & & & \\
\hline School-community relations (Y) & & & 508 & 506 & 2732 & 0.88 & High Positive Correlation \\
\hline
\end{tabular}

Result from Table 1 reveals a correlation coefficient $=0.88$. This value is high and positive, indicating that there is high and positive relationship between the award of contracts to community members and school-community relations. This implies that increase in award of contracts to community members leads to corresponding increase in schoolcommunity relations in Rivers State.

Research Question 2: What is the extent of relationship between award of scholarship to students from the community and schoolcommunity relations in Tertiary Institutions in Rivers State?

Table 2: Pearson Product Moment Correlation Analysis on the Relationship between award of scholarship to students from the community and School-community relations

\begin{tabular}{|c|c|c|c|c|c|c|c|}
\hline Variable & $\sum$ & $\sum \mathbf{2}$ & $\mathbf{N}$ & $\mathbf{D f}$ & $\sum \mathbf{X Y}$ & $\mathbf{r}$ & Decision \\
\hline Award of scholarship to students from the community (X) & 10201 & 2436 & & & & & \\
\hline School-community relations (Y) & & & 508 & 506 & 2753 & 0.81 & High Positive Correlation \\
\hline
\end{tabular}


Result from Table 2 reveals a correlation coefficient $=0.81$. This value is high and positive, indicating that there is high and positive relationship between the award of scholarship to students from the community and school-community relations. This implies that increase in award of scholarship to students from the community leads to corresponding increase in school-community relations in Rivers State.

Hypothesis 1: There is no significant relationship between award of contracts to community members and schoolcommunity relations in Rivers State.

Table 3: Transformed z-test on the Relationship between award of contracts to community members and school-community relations

\begin{tabular}{|c|c|c|c|c|c|c|c|c|c|}
\hline Variable & $\sum$ & $\sum^{2}$ & $\mathbf{N}$ & $\mathbf{D f}$ & $\sum \mathbf{X Y}$ & $\mathbf{r}$ & z-cal. & z-crit. & Decision \\
\hline Award of contracts to community members (X) & 10197 & 2123 & & & & & & & \\
\hline School-community relations (Y) & & & 508 & 506 & 2732 & 0.88 & 46.90 & 1.96 & Sig Rejected \\
\hline
\end{tabular}

Result from Table 3 reveals that a high positive relationship exists between award of contracts to community members and school-community relations. To establish the significance of the relationship, a transformed $\mathrm{z}$-value was computed and an index of 46.90 was obtained. This was compared to the critical z-value of 1.96 at the 0.05 level of significance with a degree of freedom of 506, indicating that there is a significant positive relationship between award of contracts to community members and school-community relations (calculated $\mathrm{z}=46.90<$ critical $\mathrm{z}=1.96$ at $\mathrm{p}<0.05$ and df = 506). Therefore, the null hypothesis of no significant relationship between award of contracts to community members and school-community relations is rejected. This implies that the relationship is positive and strong, and any increase in the award of contracts to community members tends to be accompanied by improvement in schoolcommunity relations in Rivers State.

Hypothesis 2: There is no significant relationship between award of scholarships to students from the community and schoolcommunity relations in Rivers State.

Table 4: Transformed z-test on the Relationship between award of scholarships to students from the community and schoolcommunity relations

\begin{tabular}{|l|c|c|c|c|c|c|c|c|c|}
\hline Variable & $\sum$ & $\sum^{2}$ & $\mathbf{N}$ & $\mathbf{D f}$ & $\sum \mathbf{X Y}$ & $\mathbf{~}$ & z-cal. & z-crit. & Decision \\
\hline Award of scholarship to students from the community (X) & 10201 & 2436 & & & & & & & \\
\hline & & & 508 & 506 & 2753 & 0.81 & 38.57 & 1.96 & $\begin{array}{l}\text { Sig } \\
\text { Rejected }\end{array}$ \\
\hline School-community relations (Y) & 10360 & 3612 & & & & & & & \\
\hline
\end{tabular}

Result from Table 4 reveals that a high positive relationship exists between award of scholarships to students from the community and school-community relations. To establish the significance of the relationship, a transformed $\mathrm{z}$-value was computed and an index of 38.57 was obtained. This was compared to the critical z-value of 1.96 at the 0.05 level of significance with a degree of freedom of 506 , indicating that there is a significant positive relationship between award of scholarships to students from the community and school-community relations (calculated $\mathrm{z}=38.57<$ critical $\mathrm{z}=1.96$ at $\mathrm{p}$ $<0.05$ and $\mathrm{df}=506)$. Therefore, the null hypothesis of no significant relationship between award of scholarships to students from the community and school-community relations is rejected. This implies that the relationship is positive and strong, and any increase in the award of scholarships to students from the community tends to be accompanied by improvement in schoolcommunity relations in Rivers State.

\section{Summary of Findings}

The findings of this study are summarized as shown below:

1. The study revealed that high positive relationship exists between award of contracts to community members and school-community relations in Rivers 
State. Therefore, the null hypothesis of no significant relationship between award of contracts to community members and school-community relations is rejected.

2. The study revealed that there is a high and positive relationship between award of scholarship to students from the host community and school-community relations in Rivers State. Therefore, the null hypothesis of no significant relationship between award of scholarships to students from the community and school-community relations is rejected.

\section{DISCUSSION OF FINDINGS}

Award of contracts to community members and school-community relations

The study revealed that high positive relationship exists between award of contracts to community members and school-community relations in Rivers State. Employment constitutes the epicenter of any consideration of the economics and social development of any country (Yesufu, 2010). This can equally be said of host communities of tertiary educational institutions. The term "Employment Quota" specifies limit on the quantity of workers hired by a firm or business, typically based on ethnic or demographic criteria. Employment quota has been used as a means of providing increased opportunities persons, women, and other groups that have been historically subject to discrimination.

It is important to note that the community will go a long way to protect the institution from any external interference. The gesture by the heads of tertiary institutions will also help in alleviating poverty, social vices and prevent other associated crises that might possibly emanate from the community. Therefore, the null hypothesis of no significant relationship between award of contracts to community members and schoolcommunity relations is rejected. This implies that the relationship is positive and strong, and any increase in the award of contracts to community members tends to be accompanied by improvement in schoolcommunity relations in Rivers State.

\section{Award of scholarship to students from the community and school-community relations}

The study revealed that there is a high and positive relationship between award of scholarship to students from the host community and school-community relations in Rivers State. Kalagbor, (2014) believed that scholarships are awarded based upon various criteria, such as need, merit, diversity and inclusion and, athletic skills, among others, or some combination of criteria. Scholarship criteria usually reflect the values and goals of the donor or founder of the award. While scholarship recipients are not required to repay scholarships, the awards may require that the recipient continue to meet certain requirements during their period of support, such as maintaining a minimum grade point average or engaging in a certain activity.

Mussazi (2010) said that scholarship award, especially to indigent and exceptionally gifted members of the community are also useful to heads of tertiary institutions when trying to promote harmonious school-community relations. Financial assistance is a necessity for many college students, particularly those planning careers that require many years of education beyond the undergraduate level. Scholarships have unique benefits and are the most desirable form of financial aid. Many are merit-based or awarded as recognition for certain achievements. Like grants, scholarships do not have to be repaid. But grants are often need-based, so scholarships are more prestigious and can enhance students resume as well as help them pay for their education. Many students graduate from college with enormous student loan debt or limit their education in an attempt to control costs. By removing financial barriers, scholarships make education and career goals easier to obtain. 
Therefore, the null hypothesis of no significant relationship between award of scholarships to students from the community and school-community relations is rejected. This implies that the relationship is positive and strong, and any increase in the award of scholarship to students from the host community tends to be accompanied by improvement in schoolcommunity relations in Rivers State.

\section{CONCLUSION}

Based on the research finding, Internal Management Integration Policies Questionnaire (award of contracts to community members and award of scholarships to students from the community) have high positive relationship to school-community relations in Rivers State.

\section{Recommendations}

Based on the findings, the following recommendations are proffered:

1. Higher institutions' administration should give full implementation to local content laws during the award of contracts in the school environment.

2. Students from the host communities with exceptional academic performance should be encouraged with the award of full scholarships.

\section{Acknowledgement: None}

\section{Conflict of Interest: None}

\section{Source of Funding: None}

\section{REFERENCES}

1. Aderounmu, W. O. \& Ehiametalor, E. T. (2015). Introduction to administration of schools. Journal of Development Council 20(1),63- 68.

2. Calhoun, C., Light, D. \& Keller, S. (2013). Understanding Sociology. New York: Pen works.

3. Famade, O. A. (2015). Funding Higher Education in Nigeria. Nigerian Educational Research

4. Ihebereme, C. (2018). Factors militating against effective performance of principals in secondary schools in Nigeria. Journal of Qualitative Education. 4(1),322-329.

5. Kalagbor, S. B. (2014). Development theories, strategies and administration, Port Harcourt: Horizon concepts.

6. Mishra, R. C. (2017). History of education administration. New Delhi: APH Publishing Corporation.

7. Mussazi, T. (2010). Educational Administration, theoretical perspective of practice and research. New York: Haper and Row Publishers.

8. Nwankwo, J. I.; Nwokafor, J. N; Ogunsanwo, O. A. \& Ighalo, A. S. (2015). Educational administration and supervision. Ibadan: Heinemann Educational Books (Nig).

9. Okoroma N. S. (2017). Perspectives of educational management, planning and policy analysis. Port Harcourt: Minson Publishers

10. Sidhu, K. S. (2017). School organization and administration. New Delhi: Sterling Publishers PVT.

11. Yesufu, T. M. (2010). The Human Factor in National Development: Nigeria. Ibadan: Spectum Books Limited.

How to cite this article: Sam-Kalagbor, Osaruchi Victoria, Osuji, Catherine U. Internal management integration policies and schoolcommunity relations in Tertiary Institutions in Rivers State. International Journal of Research and Review. 2021; 8(9): 574-581. DOI: https://doi.org/10.52403/ijrr.20210972 